\title{
THE HEPATITIS C UNTYPE-ABLE GENOTYPES, AN EMERGENCE OF QUASI-SPECIES IN HCV INFECTED PATIENTS
}

\author{
Qanita Fahim, Irfan Ali Mirza, Ayesha Khalid, Anum Imtiaz, Asad Ahmad*
}

Combined Military Hospital Lahore/National University of Medical Sciences (NUMS) Pakistan, *Avicenna Medical College, Lahore Pakistan

\begin{abstract}
Objective: To determine the frequency of Type-able and untype-able genotypes in hepatitis C infected patients, and to observe their association with gender, age, Alanine Aminotranferease and viral load.

Study Design: Cross-sectional analytical study.

Place and Duration of Study: Department of Microbiology, Combined Military Hospital, and Lahore, Pakistan from Sep 2017 to Mar 2018.

Methodology: Six hundred forty seven anti HCV antibodies positive serum samples by Enzyme Linked Immuno Sorbant Assay were received from a total of 6791 serum samples. The positive sera were subjected to qualitative PCR and quantitative real time (RT) PCR to determine pre-treatment viral load. Quantitative PCR positive sera with viral load $>500 \mathrm{IU} / \mathrm{ml}$ were further subjected to molecular genotyping by using Ohno et al method.

Result: Out of 647 positive serum samples, type-specific PCR fragments were seen in 424 sera, while $13(3.1 \%)$ of serum samples were of untype-able genotype. In all age groups genotype $3 a$ had emerged as a predominant genotype $397(93.6 \%)$, followed by $1 \mathrm{~b} 8(1.9 \%)$, 3b $4(0.9 \%)$, 1a $2(0.5 \%)$, while no sample detected to have $2 \mathrm{a}, 2 \mathrm{~b}$, $5 \mathrm{a}, 6 \mathrm{a}$ and mixed genotypes. The highest prevalence of untype-ables were seen in 61-70 age group.

Conclusion: Need of the hour is proper sequencing of untype-able genotypes via upgrading existing methodologies. It will not only help the clinicians in achieving sustained virological response but also help in identifying new genotypes/subtypes.
\end{abstract}

Keywords: Hepatitis C-virus, Genotypes, Untype-able variants.

This is an Open Access article distributed under the terms of the Creative Commons Attribution License (http://creativecommons.org/licenses/by/4.0), which permits unrestricted use, distribution, and reproduction in any medium, provided the original work is properly cited.

\section{INTRODUCTION}

Hepatitis $\mathrm{C}$ virus (HCV), was discovered in 1989. For long it was thought to be a non-A, non$B$ virus acquired after blood transfusions. Quickly this discovery led to the development of serological and molecular methods for HCV detection. Its major value was observed in transfusion set ups where Hep C screening dropped the incident of transfusion acquired infection to nil, and add another test in the panel of investigations for clinical hepatitis ${ }^{1}$.

One observes varied differences in the HCV nucleotide sequences. These variations has led to the formulation of genotypic classification of $\mathrm{HCV}$ which accommodates variants from all over the world and classify them into six main genotypes. Genotype 7, a rare genotype has also been reported. These genotypes are further divided

Correspondence: Dr Qanita Fahim, Dept of Pathology, Combined Military Hospital Lahore Pakistan

Received: 10 Mar 2019; revised received: 06 Aug 2020; accepted: 12 Aug 2020 into subtypes. A $30 \%$ sequence divergence was observed in various groups of these genotypes resulting in modifications of their antigenic properties and biological behaviour i.e. (type of treatment and response) $)^{2}$.

A Worldwide distribution has been observed in $\mathrm{HCV}$ genotypes like $1 \mathrm{a}, 2 \mathrm{a}$ and $2 \mathrm{~b}$, while in South Africa and South East Asia genotype $5 a$ and $6 a$ are common ${ }^{3}$. In USA and countries of Western Europe frequent culprits causing chronic hepatitis are $1 \mathrm{a}, 1 \mathrm{~b}, 2 \mathrm{a}, 2 \mathrm{~b}$, and $3 \mathrm{a}$ genotypes. Moreover, their frequencies may vary geographically as in south and Eastern Europe $1 \mathrm{~b}$ is frequently diagnosed as infection causing genotype while Genotype 1a and 3a are more commonly seen in drug users. In Pakistan most prevalent Genotype is 3 with $3 a$ and $3 b$ subtypes. The $3 a$ and $3 b$ subtypes are circulating with equal frequency among males and females ${ }^{3-6}$. Furthermore, prevalence of Genotype 4 is high in North Africa and Middle East $^{3}$. Mainstay of proper treatment of $\mathrm{HCV}$ in- 
fected patients rely on accurate detection of $\mathrm{HCV}$ genotype ${ }^{7}$.

Current statistics suggest that $\mathrm{HCV}$ is responsible for $>200$ million infections worldwides, and over 10 million confirmed infections in Pakistan 9 . It has listed itself as one of the leading cause of cirrhosis 27\%, Hepatocellular carcinoma (HCC) 25\%, chronic hepatitis 70\%-85\% and liver transplantation ${ }^{10-12}$. According to World Health Observatory, the leading cause of deaths Worldwide in year 2013, responsible for 1.46 million deaths was hepatitis $C$ viral infection and in years 2015-2030, 7.2 million deaths were expected ${ }^{13}$.

For the prevention and control of viral hepatitis World Health Organization (WHO) for the year 2016-2021, has announced its first Global Health Sector Strategy (GHSS). Through varied steps GHSS would not only try to achieve the chalked out health targets of 2030 Agenda but also try to combat the expected 7.2 million $\mathrm{HCV}$ associated deaths during years 2015-203014.

High mutation rate of approximately $10^{-3}$ has been observed in HCV genome. This mutation happens at each replication of a nucleotide ${ }^{15}$ which leads to formation of higher number of quasi species (untype-able) in the infected population. This error prone nature of $\mathrm{HCV}$ genome resulting in circulating large proportion of $\mathrm{HCV}$ variants in affected population is disturbing for clinicians and treating physicians as to what type and duration of therapy be selected for infected patients. Moreover, this fact is gaining popularity that these untype-able variants which we encounter during routine genotype diagnostic test are resistant to treatment ${ }^{16}$.

This study was done to determine the frequency of type-able and untype-able HCV genotypes in patients suffering from chronic hepatitis $\mathrm{C}$ and to observe the biological behaviour of untype-able genotype in terms of gender, age, Alanine Aminotranferease and viral load.

\section{METHODOLOGY}

The study was done in the department of Microbiology, Combined Military Hospital,
Lahore, Pakistan from September 2017 to March 2018. CMH Lahore serves as Primary Referral Centre for central and southern Punjab and adjacent areas of Sindh and Baluchistan. We included a total of $424 \mathrm{HCV}$ positive sera in our study which were collected from patients, who were registered in Army Health Management System (HMS) as per their consent and ethical approval of the Institutional committee from September 2017 to March 2018. Patients were selected on the basis of having chronic $\mathrm{HCV}$ infection and were seropositive for anti-HCV antibodies by thirdgeneration ELISA (Adaltis, Milano, Italy).

Selection of serum samples was done on non probability consecutive basis for the study after taking proper consent in written form from each patient. Duplicate samples were excluded from the study. The questionnaire included age, sex, rank, name, number, duration of having HCV infection, Liver Function Tests, Ultra sound abdomen report, quantitative estimation of $\mathrm{HCV}$ RNA to conclude association along with complete address and phone numbers.

Sera which were positive for HCV RNA were quantified as per manufacturer's instructions by using Real Time PCR System with real time specific software using HCV-RNA quantification kits (Robogene, AJ Roboscreen $\mathrm{GmbH}$, Germany). The Real Time System undergoes amplification, identification and quantification at the same instant using fluorescent probes (HCV RNA: FAM, IC RNA: VIC/JOE) and results could be visualised on computer screen. It has a very low detection limit of $70 \mathrm{IU} / \mathrm{mL}$. Only those sera having a viral load of $>500 \mathrm{IU} / \mathrm{ml}$ were further selected for molecular genotyping by using Ohno et al method ${ }^{17}$.

All the $424 \mathrm{HCV}$ positive sera (qualitatively and quantitatively) were genotyped by the Ohno et al method, as described previously ${ }^{17}$. In Ohno et al, method for genotyping, two different primer mixtures were used. Mix-A had a set of primers for the detection of genotypes $2 a, 1 b, 2 b$ and $3 b$ genotypes and mix- $B$ had a primer set to detect genotypes 1a, 3a, 4, 5a and 6a. Amplification was 
carried out in two rounds. The amplified product of first round of PCR was then subjected to second round nested PCRs for each sample. An $08 \mu \mathrm{l}$ of the second-round PCR product was electrophoresed on a $2 \%$ agarose gel, stained with Ethidium bromide, evaluated under UV light and compared with $1000 \mathrm{bp}$ ladder. Samples with known genotypes were run with each round of nested PCR as controls.

The expected sizes of the genotype-specific bands amplified by PCR typing were as follows: tive for anti-HCV antibodies by using 3rd generation ELISA. After confirmation through qualitative PCR when these 647 serum samples were subjected to quantitative PCR, only 424 samples showed viral titres of $>500 \mathrm{IU} / \mathrm{ml}$ whereas, 223 samples either showed a titre of $<5001 \mathrm{U} / \mathrm{ml}$ or no titre at all (detection limit $70 \mathrm{IU} / \mathrm{mL}$ ). They were excluded from the study and rest of the samples were further tested for specific genotype bands. Out of these 424 serum samples specific genotype bands were seen in 411 serum samples

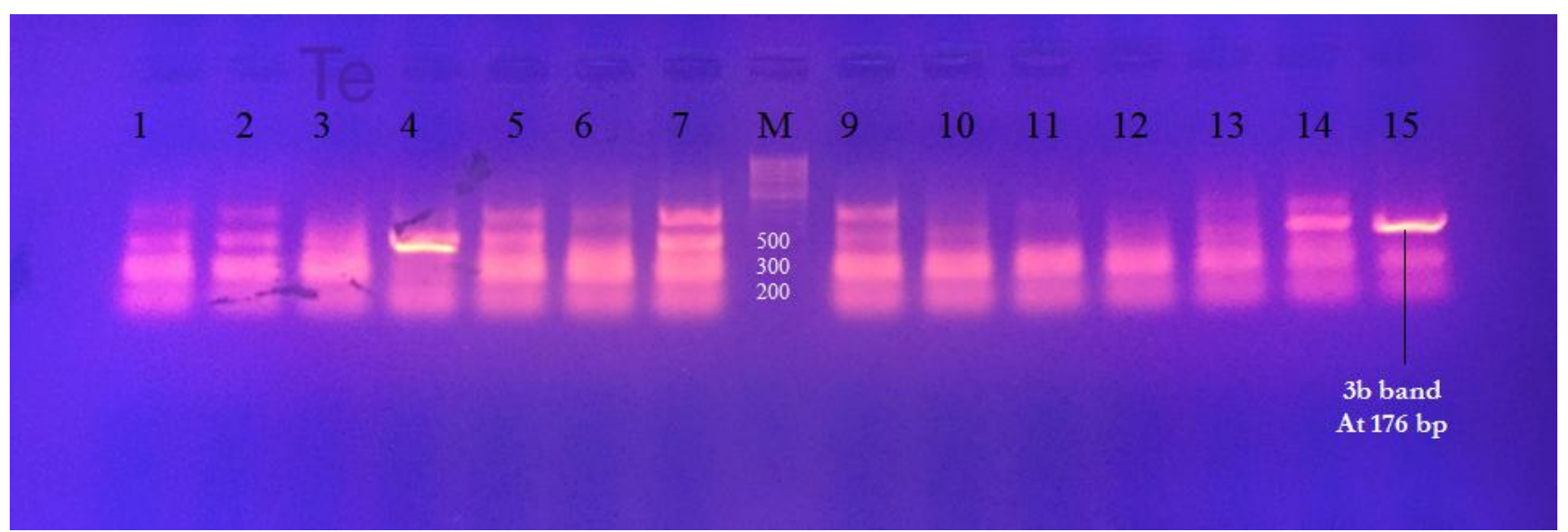

Figure-1: Agarose Gel electrophoresis (2\%) showing patterns of PCR products from different HCV specimens by multiplex PCR ${ }^{17}$. Lane 1 shows negative control, lanes 2,3,5,6,7,9,10,11,12,13,14, showing presence of untype-able genotypes by showing no specific bands. lanes 4 and 15 showing bands of genotype $3 \mathrm{~b}$. Lane M shows $50-\mathrm{bp}$ DNA ladder marker.

genotype 1a, 208 bp in size; genotype 1b, 234 bp; genotype 2a, 139 bpand $190 \mathrm{bp}$. Expected sizes of the genotype $2 b, 3 a, 3 b, 4,5 a$ and $6 a$ specific bands were 337 bp, 232 bp, 176 bp, 99 bp, 320 bp; and $336 \mathrm{bp}$.

SPSS version 21.0 for Windows was used for the analysis of data and statistics. The results for all variables were entered in the form of rates (\%). T-test and chi-square tests were applied to find out associations used. Log- Likelihood Ratio test (LR) and Cramer's V statistics were applied to find out the significance of association in terms of $p$-value amongst untype-ables and the categorical variables. The $p$-value of $<0.05$ was considered significant.

\section{RESULTS}

From a total of 6791 serum samples, 647 samples were positive while 6144 were found nega- whereas, 13 samples $(3.1 \%)$ were found to have untype-able genotypes as a specific genotype band was absent in these samples (fig-1). Further-

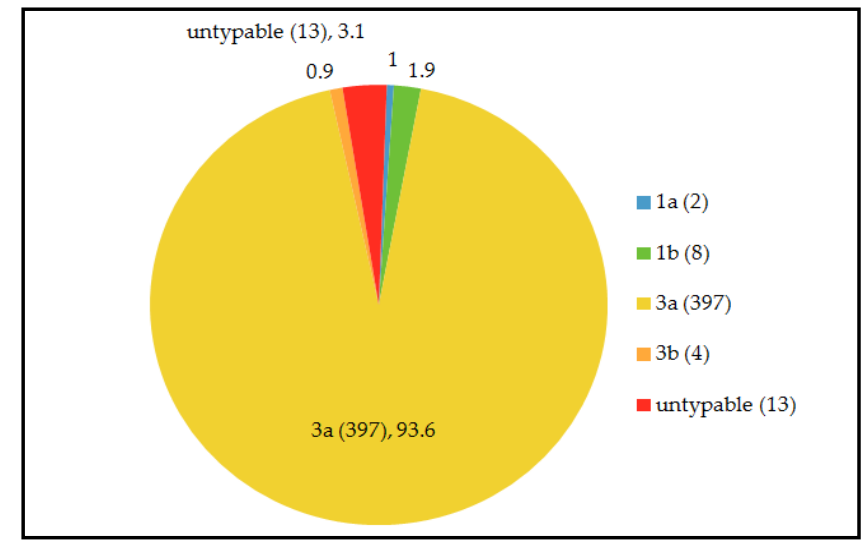

Figure-2: Frequency of various HCV genotypes $n=424$.

more, in these 411 sera genotype 3 a emerged as a predominant genotype $(93.6 \%)$, followed by $1 \mathrm{~b}$ 
$(1.9 \%), 3 \mathrm{~b}(0.9 \%), 1 \mathrm{a}(0.5 \%)$ respectively, while no sample was detected to have $2 a, 2 b, 6 a$ and mixed

Table-I: Percentages of $\mathrm{HCV}$ genotypes in different age groups of $\mathrm{HCV}$ patients $(\mathrm{n}=424)$.

\begin{tabular}{|c|c|c|c|c|c|}
\hline \multirow{2}{*}{ Age Group } & \multicolumn{5}{|c|}{ Genotypes } \\
\hline & \multirow{2}{*}{$\frac{1 a}{1}$} & \multirow{2}{*}{$\frac{1 b}{-}$} & \multirow{2}{*}{$\begin{array}{l}3 \mathbf{a} \\
33\end{array}$} & \multirow{2}{*}{$\begin{array}{c}3 b \\
1\end{array}$} & \multirow{2}{*}{$\begin{array}{c}\begin{array}{c}\text { Un- } \\
\text { type }\end{array} \\
1\end{array}$} \\
\hline \begin{tabular}{l|l}
$21-30$ & count \\
\end{tabular} & & & & & \\
\hline $\begin{array}{l}\text { \%age within Age } \\
\text { group }\end{array}$ & 2.8 & - & 91.7 & 2.8 & 2.8 \\
\hline $\begin{array}{l}\text { \%age within } \\
\text { Genotype }\end{array}$ & 50 & - & 83 & 25 & 7.7 \\
\hline count & - & - & 53 & - & 3 \\
\hline $\begin{array}{l}\text { \%age within Age } \\
\text { group }\end{array}$ & - & - & 94.6 & - & 5.4 \\
\hline $\begin{array}{l}\text { \%age within } \\
\text { Genotype }\end{array}$ & - & - & 13.4 & - & 23.1 \\
\hline 41-50 count & - & - & 83 & - & - \\
\hline $\begin{array}{l}\% \text { age within Age } \\
\text { group }\end{array}$ & - & - & 100 & - & - \\
\hline $\begin{array}{l}\% \text { age within } \\
\text { Genotype }\end{array}$ & - & - & 20.9 & - & - \\
\hline \begin{tabular}{l|l}
$51-60$ & count
\end{tabular} & - & 6 & 127 & 1 & 3 \\
\hline $\begin{array}{l}\% \text { age within Age } \\
\text { group }\end{array}$ & - & 4.4 & 92.7 & 0.7 & 2.2 \\
\hline $\begin{array}{l}\text { \% age within } \\
\text { Genotype }\end{array}$ & - & 75 & 32 & 25 & 23.1 \\
\hline \begin{tabular}{|l|l|}
$61-70$ & count \\
\end{tabular} & 1 & 2 & 69 & 1 & 5 \\
\hline $\begin{array}{l}\% \text { age within Age } \\
\text { group }\end{array}$ & 1.3 & 2.6 & 88.5 & 1.3 & 6.4 \\
\hline $\begin{array}{l}\% \text { age within } \\
\text { Genotype }\end{array}$ & 50 & 25 & 17.4 & 25 & 38.5 \\
\hline \begin{tabular}{l|l}
$71-80$ & count
\end{tabular} & - & - & 25 & 1 & 1 \\
\hline $\begin{array}{l}\% \text { age within Age } \\
\text { group }\end{array}$ & - & - & 92.6 & 3.7 & 3.7 \\
\hline $\begin{array}{l}\% \text { age within } \\
\text { Genotype }\end{array}$ & - & - & 6.3 & 25 & 7.7 \\
\hline \begin{tabular}{l|l|}
$81-90$ & count \\
\end{tabular} & - & - & 7 & - & - \\
\hline $\begin{array}{l}\% \text { age within Age } \\
\text { group }\end{array}$ & - & - & 100 & - & - \\
\hline $\begin{array}{l}\% \text { age within } \\
\text { Genotype }\end{array}$ & - & - & 1.8 & - & - \\
\hline \begin{tabular}{l|l}
$91-100$ & count
\end{tabular} & 2 & 8 & 397 & 4 & 13 \\
\hline $\begin{array}{l}\% \text { age within Age } \\
\text { group }\end{array}$ & 0.5 & 19 & 94 & 0.9 & 3.1 \\
\hline $\begin{array}{l}\% \text { age within } \\
\text { Genotype }\end{array}$ & 100 & 100 & 10 & 100 & 100 \\
\hline
\end{tabular}

genotype. Genotype 7 was out of scope of available PCR method (fig-2).
Table-I shows cross tabulation of HCV genotypes among studied patients with gender. Out of $424 \mathrm{HCV}$ patients, there were 217 (51.2\%) females and 207 (48.8\%) were males. Mean age with standard error of mean was (51.64 \pm 0.675$)$,

Table-II: Gender wise distribution of HCV genotypes among the studied patients $n=424$.

\begin{tabular}{|c|c|c|c|c|c|c|}
\hline \multicolumn{7}{|c|}{ Genotypes } \\
\hline & $1 \mathbf{a}$ & $1 b$ & $3 a$ & $3 b$ & $\begin{array}{l}\text { Un- } \\
\text { type }\end{array}$ & Total \\
\hline \multicolumn{7}{|l|}{ Gender } \\
\hline \begin{tabular}{l|l} 
Female & count \\
\end{tabular} & 1 & 3 & 203 & 2 & 8 & 217 \\
\hline $\begin{array}{l}\% \text { age with } \\
\text { Gender }\end{array}$ & 0.5 & 1.4 & 93.5 & 0.9 & 3.7 & 100 \\
\hline $\begin{array}{l}\text { \% age with } \\
\text { Genotype }\end{array}$ & 50 & 37.5 & 51.1 & 50 & 61.5 & 51.2 \\
\hline count & 1 & 5 & 194 & 2 & 5 & 207 \\
\hline $\begin{array}{l}\text { \% age with } \\
\text { Gender }\end{array}$ & 0.5 & 2.4 & 93.7 & 1 & 2.4 & 100 \\
\hline $\begin{array}{l}\text { \% with } \\
\text { Genotype }\end{array}$ & 50 & 62.5 & 48.9 & 50 & 38.5 & 48.8 \\
\hline count & 2 & 8 & 397 & 4 & 13 & 424 \\
\hline $\begin{array}{l}\text { \% age } \\
\text { Prevalence }\end{array}$ & 0.5 & 1.9 & 93.6 & 0.9 & 3.1 & 100 \\
\hline$p$-value & 0.973 & $\begin{array}{c}0.43 \\
5\end{array}$ & $\begin{array}{c}0.94 \\
2\end{array}$ & $\begin{array}{c}0.96 \\
2\end{array}$ & $\begin{array}{c}0.44 \\
8\end{array}$ & 100 \\
\hline
\end{tabular}

Table-III: Summary of statistical tests / strength of association among all genotypes vs. gender, ALT, viral titres and age group in $n=424 \mathrm{HCV}$ suspected patients.

\begin{tabular}{l|c|c|c|c}
\hline & \multicolumn{4}{c}{ Method } \\
\hline & \multicolumn{2}{|c|}{ Likelihood Ratio } & \multicolumn{2}{c}{$\begin{array}{c}\text { Strength of } \\
\text { Association }\end{array}$} \\
\hline $\begin{array}{l}\text { L-R } \\
\text { statistics }\end{array}$ & $\begin{array}{c}p- \\
\text { value }\end{array}$ & $\begin{array}{c}\text { Cramer' } \\
\text { s V }\end{array}$ & $\begin{array}{c}p- \\
\text { value }\end{array}$ \\
\hline $\begin{array}{l}\text { Genotype* } \\
\text { Gender }\end{array}$ & $\begin{array}{c}11.175 \\
(10)\end{array}$ & 0.344 & 0.355 & $* 0.001$ \\
\hline $\begin{array}{l}\text { Genotype* } \\
\text { Age group }\end{array}$ & $\begin{array}{c}44.106 \\
(40)\end{array}$ & 0.302 & & $* 0.001$ \\
\hline $\begin{array}{l}\text { Genotype* } \\
\text { ALT }\end{array}$ & $\begin{array}{c}159.922 \\
(545)\end{array}$ & $\mathrm{NS}$ & 0.611 & $* 0.001$ \\
\hline $\begin{array}{l}\text { Genotype } \\
\text { Quantitativ } \\
\text { e PCR }\end{array}$ & $\begin{array}{c}302.272 \\
(2040)\end{array}$ & $\mathrm{NS}$ & 0.989 & 0.195 \\
\hline $\begin{array}{l}{ }^{*} 0.001 \text { shows highly significant result, NS; Not Significant, Test } \\
\text { statistics along with degree of freedom are mentioned in brackets. }\end{array}$
\end{tabular}

and age range was 20-92 years. Distribution of genotypes was equal between both the sexes. Moreover, no significant association had been seen of any genotype with gender, as all the $p$ values were greater than 0.05 . 
In this table, a comparison had been shown of percentages of a given genotype within an age group with that of another age group. For example, the percentages of the untype-able genotype within age-group for age categories 21-30, 31-40, $41-50,51-60,61-70,71-80$ and 80 were $2.8 \%, 5.4 \%$, $0 \%, 2.2 \%, 6.4 \%, 3.7 \%$ and $0 \%$. Highest per-centage of untype-able genotype and prevalence within genotypes $38.5 \%$ was seen in $61-70$ age-group. Data had shown reduced number of untype-able genotypes in extreme of ages. Whereas, the highest prevalence of genotype $3 a$ is seen in $41-50$ age category $(100 \%)$ with highest prevalence within genotypes was in age category 21-30.

Table-III shows an effort that had been done to calculate strength of association among all the genotypes vs. gender, ALT, viral titres through quantitative PCR and different age groups. Significant association was seen between age groups, genders and ALT and genotypes as $p$-value observed was $<0.001$. Same tests when applied on untype-ables with ALT, quantitative PCR, age groups and gender did not give any results due to small sample size.

So in order to observe biological behaviour of untype-ables we had classified Pretreatment viral titre into categories as high $(>80,00000 \mathrm{IU} /$ $\mathrm{ml})$ and low $(<60,0000 \mathrm{IU} / \mathrm{ml})$ for untype-able genotypes. HCV viral titre was seen high $(>80$, $00000 \mathrm{IU} / \mathrm{ml}$ ) in $8 / 13$ cases while rest of the $5 / 13$ cases had shown low viral titres between 1000$8000 \mathrm{IU} / \mathrm{ml}$, so untypability could be attributed to both, low viral titres and high rate of mutations. Untypability was confirmed after running the $\mathrm{HCV}$ serum specimens in both the mixes. Serum specimens having Genotype $3 b$ were used as positive control.

\section{DISCUSSION}

Many reports published in recent 4 years from within the country and abroad clearly indicates towards an upward trend of untype-able genotypes in HCV seropositive. Samples ${ }^{18-24}$. According to a recent review article published by Abdul-waheed et al, concluding results of 4534 HCV patient samples during the years 2008-2016 showed that $11.51 \%$ samples were untype-able stressing upon the fact that this issue should be resolved on priority basis ${ }^{19}$.

Interestingly, our current study indicates a small chunk of untype-able HCV subtypes i.e,. (3.1\%) as compared to Waheed et al where a considerable number $(11.51 \%)$ of samples fall in this category suggesting not only a well controlled drug regulation system in Army but also raises the question as what future we are heading towards if we will not ensure compliance ${ }^{19}$.

These untype-able subtypes of HCV genome pose complications both diagnostically and therapeutically15,19,21.

Question arises as how these $\mathrm{HCV}$ variants produce in a population. According to literature every individual carries a slightly different variant of its own genotype in blood. As time passes these variants due to pressures from host immune system ${ }^{3,11,15}$, persistent infection ${ }^{4,12}$, treatment with Interferone, ribavarin in non-responders $3,7,15,16,21$, develop greater genetic diversity. These variants/quasi species continue to evolve in an individual. Besides creating confusion for clinician as of what duration and type of treatment to be advised to these patients the brighter side of these quasi species is that their molecular analysis can be used to prove linkages of infections from mother to infant, in concordant sexual couples, to provide a clue for nosocomial transmission of infection between a health care provider and patient and between a needle stick injury recipient to the source of infection ${ }^{15,16}$.

In developed countries, sequencing is performed in routine for the determination of underlying subtype in untype-able case ${ }^{17,19}$. However, in Army setups and in Pakistan, both the treatment and its duration are ascertained in term of viral titres of $\mathrm{HCV}$ (qualitative and quantitative detection) and type-able genotypes, which is a standard way of estimation of therapy duration. No sequence determination for underlying subtype in untype-able cases has yet been explored 3,7 . Furthermore, with emergence of these untypeable variants, requirement is generated for an 
updated genotyping assay, based on data of indigenous viral sequences, which will have the capacity to accommodate these outliers or untypeables. These quasi species are beyond the scope of our genotypic methods and are contributing towards misdiagnosis and mistreatment resulting in non-responsiveness to the treatment regimen of interferon or direct acting antivirals (DAA) ${ }^{16}$, 19-21.

Is this untypability is because of the sequencing method? as there are various methods in vogue for HCV genotyping e.g type-specific PCR, line probe hybridization assay (LiPA), genome sequencing, and restriction fragment length polymorphism (RFLP) ${ }^{19,25}$. In Pakistan two methods Ohno et al, method and Idrees et al method are generally practiced ${ }^{2,17}$. At our centre type specific PCR method devised by Ohno et al is used to detect six types and subtypes of HCV genotypes (1997) ${ }^{17}$. Method proposed by Idrees (2008) has more specificity as it is developed in the light of local sequences, excluding foreign sequences which could be one of the reason for untype-ables in our study. However various studies conducted in Pakistan, used Idrees et al, method had reported presence of untype-ables as well, further suggesting lack of complete sequencing ability of this method too $18,20,21$.

In our study a correlation was tried to calculate between genotypes and gender. It was concluded that there were no variations in distribution of HCV genotypes amongst male 207 (48.8\%) and females $(217,51.2 \%)$ and was equally distributed between both the sexes with no significant difference $(p>0.05)$. This evidence is supported by other studies as well where there was no variation found in distribution $4,8,19$.

The results of the present study indicate that highest \% prevalence of untype-ables was seen between 61-70 age group with percentage prevalence of untype-able genotype of $38.5 \%$. It has already been reported that HCV genotype distribution varies with age in both male and female patients $19,21,25$. This could be seen in our study as well with most of the untype-ables seen in older age group.

Further analysis regarding age groups, ALT and Gender with all genotypes, shows significant association $(p<0.001)$ through Cramer's v-test (table-III) suggesting that HCV irrespective of genotype invariably causes hepatic damage, its \% prevalence varies with age and has an equal distribution among both the sexes .

Mainstay of $\mathrm{HCV}$ standard treatment is to achieve sustained viral response. DAA/interferon therapy is very costly and has varied results against different genotypes ${ }^{20}$. Although, outcome of DAA therapy is very promising with very high SVR but the major hurdle is high cost $3,7,15,20$. In Pakistan, the allocated budget for health is already pretty low (just $2.7 \%$ of GDP) ${ }^{3,22}$ and without knowledge of causative genotype, it is difficult for clinicians to start the therapy.

\section{CONCLUSIONS}

Untype-able genotypes do exist in our stream of patients and showed significant association with ALT levels ( $p$-value 0.001). Hereby, stressing the fact that untype-able genotypes do have new genotype/subtypes and should be properly sequenced to help clinicians to attain sustained viral response. By exploring the phenomenon of untypability one would be able to tackle the forthcoming giant of $\mathrm{HCV}$ therapy resistance. This surge of untype-ables is an eye opener and promulgates the need of a well developed surveillance system.

\section{CONFLICT OF INTEREST}

This study has no conflict of interest to be declared by any author.

\section{REFERENCES}

1. Alter MJ. Epidemiology of hepatitis C virus infection. World J Gastroenterol 2007; 13(2): 2436-41.

2. Idrees M. Development of an improved genotyping assay for the detection of hepatitis $C$ virus genotypes and subtypes in Pakistan. J Virol Methods 2008; 150(1): 50-56.

3. Waheed Y. Effect of interferon plus ribavirin therapy on hepatitis $C$ virus genotype 3 patients from Pakistan: treatment response, side effects and future prospective. Asian Pacific J Tropical Med 2015; 14(2): 85-89. 
4. Ali A, Nisar M, Ahmad H, Saif N, Idrees M, Bajwa M. Determination of $\mathrm{HCV}$ genotypes and viral loads in chronic $\mathrm{HCV}$ infected patients of Hazara Pakistan. Virol J 2011; 8(1): 466.

5. Khan T, Mehr M, Ullah H, Khan H, Iman N. Frequency of hepatitis $C$ genotypes in the north of Pakistan. Gomal J Med Sci 2014; 12(1): 9-06.

6. Akhtar M, Majeed S, Jamil M, Rehman A. Hepatitis C virus infection among injecting drug users in Lahore,Pakistan:A cross sectional study. Pak J Med Sci 2016; 32(2): 373-78.

7. Vermehren J, Sarrazin C. New HCV therapies on the horizon. Clinical Microbiol Infect 2011; 17(1): 122-34.

8. Afzal MS, Elreheem A, Ragaa A, Wahid A. HCV Genotype 4; A Brief Review. J Gastroenterol Hepatol Res 2014; 3(2): 968-76.

9. Waheed Y, Shafi T, Safi SZ, Qadri I. Hepatitis C virus in Pakistan: a systematic review of prevalence, genotypes and risk factors. World J Gastroenterol 2009; 15(2): 5647-53.

10. Lauer G, Walker B. Hepatitis C virus infection. N Engl J Med 2001; 345(1): 41-52.

11. Zaman N, Asad J, Raza A, Raja K, Akhter S, Mahmood M, et al. Detection of HCV RNA and NS5A protein in peripheral blood mononuclear cells after sustained Virological response may cause viral relapse. Wor J of Gastroenterol 2015; 47(4): 981-87.

12. Perz JF, Armstrong GL, Farrington LA, YJF H, Bel BP. The contributions of hepatitis $B$ virus and hepatitis $C$ virus infections to cirrhosis and primary liver cancer worldwide. J Hepatol 2006: 45529-38

13. WHO: Global Health Observatory. Available from (Internet). [06 May 2016]. https://www.who.int/data/gho.

14. Prevention and Control of Viral Hepatitis Infection: Framework for Global Action [Internet]. 3 April 2016. https://www.paho. org/en/documents/ prevention-control-viral-hepatitis-infectionframework-global-action-2012.

15. Powdrill MH, Tchesnokov EP, Kozak RA, Russell RS, Martin R, Svarovskaia ES, et al. Contribution of a mutational bias in hepatitis $C$ virus replication to the genetic barrier in the development of drug resistance. Proc Natl Acad Sci USA 2011; 108(2): 20509-13.
16. Puig-Basagoiti F, Forns $X$, Furcic I. Dynamics of hepatitis $C$ virus NS5A quasispecies during interferon and ribavirin therapy in responder and non-responder patients with genotype $1 \mathrm{~b}$ chronic hepatitis C. J Gen Virol 2005; 86(1): 1067-75.

17. Ohno O, Mizokami M, Wu RR, Saleh MG, Ohba K, Orito E, et al. New hepatitis $C$ virus (HCV) genotyping system that allows for identification of HCV genotypes $1 \mathrm{a}, 1 \mathrm{~b}, 2 \mathrm{a}, 2 \mathrm{~b}, 3 \mathrm{a}, 3 \mathrm{~b}, 4,5 \mathrm{a}$, and 6a. J Clin Microbiol 1997; 35(1): 201-07.

18. Nazir N, Jan M R, Amjad A, Ali M, Idrees M, Nisar M, et al. Prevalence of hepatitis- $C$ virus genotypes and potential transmission risks in Malakand Khyber Pakhtunkhwa, PakistanNazir et al. Virol J 2017; 14(2): 160-69.

19. Khan AW, Nawab S, Nasim Z, Khan AH, Ahmad SI, Zahir F. Pattern of hepatitis $C$ virus genotypes and subtypes circulating in war-stricken Khyber Pakhtunkhwa, Pakistan: Review of published literature. Asian Pacific J Tropical Med 2017; 10(10): 1-6.

20. Gul A, Ahmed J, Zahir F, Khan IA, Ali I. New pattern of HCV subtypes distribution in the Khyber Pakhtunkhwa province of Pakistan. Braz J Infect Dis 2016; 20(1): 107-08.

21. Waqas M, Parveen F, Waqar M, Ali A, Khan MA, Wasim M, et al. Distribution pattern of various genotypes of HCV circulating in district Mardan, Khyber Pakhtunkhwa, Pakistan. Adv Biol Res 2015; 9(2): 69-74.

22. Afzal MS, Khan MY, Ammar M, Anjum S, Zaidi NS. Diagnostically untypable hepatitis $C$ virus variants: It is time to resolve the problem. World J Gastroenterol 2014; 20(46): 17690-92.

23. Waqar M, Rehman H, Khan AU, Noor AA, Ali A, Wasim M, et al. Frequency Dis- tribution of Hepatitis C Virus Genotypes in District Karachi, Pakistan. J Gastroenterol Hepatol Res 2014; 3(1): 1035-38.

24. Ali S, Ahmed A, Khan RS, Khan S, Humayun M, Khan SA, et al. Genotyping of HCV RNA reveals that $3 a$ is the most prevalent genotype in Mardan, Pakistan. Adv Virol 2014; 2014(1): 606201.

25. Waqar M, Khan AU, Rehman HU, Idrees M, Wasim M, Ali A, et al. Determination of hepatitis $C$ virus genotypes circulating in different districts of Punjab (Pakistan). Eur J Gastroenterol Hepatol 2014; 26(10): 59-64. 